\title{
Perifosine downregulates $M D R 1$ gene expression and reverses multidrug-resistant phenotype by inhibiting PI3K/Akt/NF-kB signaling pathway in a human breast cancer cell line
}

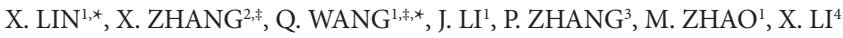 \\ ${ }^{1}$ Department of Pathology, Provincial Hospital affiliated to Shandong University, Jinan 250021, China; ${ }^{2}$ Department of Pathology, Medical School \\ of Shandong University, Jinan 250012, China; ${ }^{3}$ Institution of Biochemistry and Molecular Biology, Medical School of Shandong University, Jinan \\ 250012, China; ${ }^{4}$ Surgery of Breast and Thyroid, Provincial Hospital affiliated to Shandong University, Jinan 250012, China
}

*Correspondence: wangqiangxiu@163.com

${ }^{*}$ Contributed equally to this work.

Received September 3, 2011 / Accepted November 4, 2011

\begin{abstract}
P-glycoprotein (P-gp)-mediated multidrug resistance (MDR) is the major clinical impediment to chemotherapy of breast cancers. Down-regulation of PI3K/Akt pathway has been described as related to reversal of MDR in cancer cells. Here, we investigated the reversal effect on MDR phenotype of perifosine, a new Akt inhibitor, in breast cancer cell lines. In this study, MCF-7/ADM cells and MCF-7 cells were treated with different concentrations of perifosine. Our results suggested that perifosine reversed MDR partially by downregulation of P-gp expression and inhibition of PI3K/Akt/NF- $\kappa B$ pathway in the MCF-7/ADM cell line. The novel Akt inhibitor perifosine may be a promising new drug due to its ability to reverse MDR in human breast cancer cells.
\end{abstract}

Key words: perifosine, PI3K/Akt, breast cancer, multidrug resistant gene 1, P-glycoprotein

Multidrug resistance (MDR) is a major reason for failure of chemotherapy-based treatment of breast cancer, in which cells become refractory to many structurally and functionally unrelated chemotherapeutic drugs[1]. In clinical situation, MDR is often associated with overexpression of the MDR1 gene product, $\mathrm{P}$-glycoprotein (P-gp), which is the most important multidrug resistant transporter by reducing the concentration of the intracellular anticancer drugs [2]. Inhibition of P-gp expression or function has become an important approach aimed to reverse P-gp-mediated MDR and improve the efficacy of chemotherapy. However, the use of many reversal compounds has been limited because of pharmacokinetic interactions with anticancer drugs and serious side-effects.

Recently, much attention has been focused on the involvement of the PI3K/Akt cell signal transduction pathway in MDR [3; 4; 5]. The PI3K/Akt signaling pathway is one of the most important signaling pathways in the control of multiple biological processes in cells through activation of the serine/ threonine protein kinase Akt, which is the key downstream factor. Once overactivated, Akt can phosphorylates multiple substrates and downstream effectors such as members of the
Forkhead family, caspase family, cell cycle protein family and nuclear factor $-\kappa \mathrm{B}(\mathrm{NF}-\kappa \mathrm{B})$, which contribute collectively to promote cell proliferation, malignancy, invasion and metastasis [6; 7]. Numerous research studies have shown that the hyperactivation of Akt occurred in major human cancers including breast cancer [8; 9]. Some findings have also demonstrated that the activity of Akt in tumor cells increased after exposure to anticancer chemotherapy drugs through activation of the Ras pathway that leads to resistance to other anticancer drugs [10]. Although P-gp is found in a parallel relationship with Akt activity, the mechanism of regulation of MDR1 by Akt is unclear.

Many small molecular inhibitors of the PI3K/Akt signaling pathway can increase the chemosensitivity of cancer cells to anticancer drugs $[11 ; 12]$. These inhibitors have been reported to include Akt-I-1, Akt-I-2 and perifosine [13; 14; 15]. Garcia et al.[15] reported that the PI3K/Akt pathway is involved in MDR in lymphoma cell lines and PI3K/Akt inhibition in which LY294002 correlates down-regulation of NF- $\kappa \mathrm{B}$ activity and inhibition of P-gp function. In addition, Barancik et al [11] reported the possible involvement of the PI3K/Akt pathway 
in modulation of MDR mediated by P-gp in the L1210/VCR cell line. These results suggest that blockage of the PI3K/Akt pathway might partially reverse P-gp-mediated MDR.

Perifosine is a potentially more novel Akt inhibitor that targets the lipid-binding pleckstrin homology $(\mathrm{PH})$ domain of Akt by prevention of cell membrance recruitment. It has been reported that perifosine may influence the resistance to anticancer-drugs through regulation of the expression of P-gp in leukemia MDR cells [16]. However, the activity of perifosine has not been tested in human tumor cells that overexpress Pgp. In this study, to find a promising drug to overcome MDR, we investigated whether inhibition of Akt via perifosine could reverse the MDR phenotype partially in P-gp-mediated multidurg-resistant human breast cancer MCF-7/ADM cells and primarily look at the probable mechanism involved.

\section{Materials and Methods}

Cell lines and cell culture. The parental drug-sensitive human MCF-7 breast cancer cell line and the multidrug-resistant MCF-7/ADM subline were obtained from the National Cancer Institute in the USA. The two cell lines were grown in RPMI 1640 medium (Hyclone), supplemented with 10\% heat-inactivated fetal bovine serum(FBS), in an atmosphere of $5 \% \mathrm{CO}_{2}$ at $37^{\circ} \mathrm{C}$.

Cell viability and Cell chemosensitivity assay by MTT in vitro. MTT(3-(4,5-dimethylthiazol-2-yl)-2,5-diphenyltetrazolium bromide) assays were performed to assess the chemosensitivity of cells to perifosine(Frankfurt, Germany), adriamycin and vinblastine. Briefly, Cells were seeded in 96-well plates at a density of $5 \times 10^{3}$ cells/well and cultured overnight; perifosine at a range of concentrations $(5,10$ or $15 \mu \mathrm{M}$ ) in medium that contained adriamycin(or vinblastine) was then added to the cells for another $24 \mathrm{~h}$. A stock solution of perifosine $(40 \mathrm{mM})$ was prepared in dimethylsulfoxide (DMSO); cells cultured in the presence DMSO alone and with the same perifosine concentrations served as the negative control. At the end of the incubation, $20 \mu \mathrm{l}$ MTT solution $(4 \mathrm{mg} / \mathrm{ml})$ and $10 \mu \mathrm{l}$ of $0.1 \mathrm{M}$ sodium succinate were added to each well and the cells were incubated for a furthe $4 \mathrm{~h}$ at $37^{\circ} \mathrm{C}$ in the dark. The intracellular MTT stain was solubilized with $50 \mu$ of dimethyl sulfoxide (DMSO)(Sigma) and mixed thoroughly for $15 \mathrm{~min}$. Spectrometric absorption at a wavelength of $570 \mathrm{~nm}$ was measured on a microplate reader (Bio-Ted, USA). The survival rates of the cells were calculated as follows: cell viability $=[$ A570(anticancer drug+)/A 570(anticancer drug-) $] \times 100 \%$. Growth inhibition (\%) $=100$ - cell survival rate (\%). A dose-response curve was plotted and $\mathrm{IC}_{50}$ values were calculated from at least three independent experiments. The multidrug resistance reversal effect was evaluated as a decrease in $\mathrm{IC}_{50}$ for adriamycin or vincristine induced by the presence of perifosine. Fold changes in reversal were calculated by comparison of $\mathrm{IC}_{50}$ for anticancer drugs (adriamycin) to $\mathrm{IC}_{50}$ for anticancer drugs plus perifosine in MCF-7/ADM cells. All analyses were performed in three separate experiments.
Detection of mdr1 mRNA expression by reverse transcription polymerase chain reaction (RT-PCR). Total RNA was obtained from cells by using an RNA Isolation Kit (TaKaRa). The RNA samples were reverse transcribed using a reverse transcriptase kit (TaKaRa) with random primers in a 20- $\mu$ l final volume and in accordance with the manufacturer's protocols. Quantitative real-time PCR (qPCR) was used to detect P-gp mRNA. qPCR was performed using SYBR Green Real-time PCR MasterMix (TOYOBO). The sequences of the primers used for amplification of mRNA are as follows, MDR1: sense: 5'-CCC ATC ATT GCA ATA GCA GG-3', antisense: 5'-GTT CAA ACT TCT GCT CCT GA-3'; and $\beta$-actin: sense: 5'-ACC CCC ACT GAA AAA GAT GA-3', antisense:5'-ATC TTC AAA CCT CCA TGA TG-3'. The final reaction volume was $25 \mu \mathrm{l}$, and an iCycler iQ Real-time PCR Detection System (Bio-Rad) was used for qPCR. The amplification data were calculated using the $\Delta \Delta \mathrm{Cq}$ method which was used to calculate relative mRNA expression. The relative target gene expression was calculated using the fomula for $2^{-\Delta \Delta \mathrm{Cq}}$, where $\Delta \Delta \mathrm{Cq}=$ target $\mathrm{Cq}-$ control $\mathrm{Cq}, \Delta \Delta \mathrm{Cq}=\Delta \mathrm{Cq}$ target $-\Delta \mathrm{Cq}$ calibrator. The PCR products $(10 \mu \mathrm{l})$ were electrophoresed in $2 \%$ agarose gel containing ethidium bromide and visualized by UV illumination to identify the specifity.

Quantifying the P-gp, Akt, p-Akt(Ser473) and NF-kB p65 expression by Western blotting. Western blotting was peformed as described previously[17]. Cells $\left(2 \times 10^{5}\right)$ were seeded in $25 \mathrm{~cm}^{2}$ flasks and were incubated for $24 \mathrm{~h}$ at $37^{\circ} \mathrm{C}$ before treatment. For extraction of total cell proteins, cells were lysed in homogenization buffer that consisted of $50 \mathrm{mM}$ Tris- $\mathrm{Hcl}$ (pH8.0), $150 \mathrm{mM} \mathrm{NaCl}, 0.2 \%$ sodium azide, $0.1 \%$ sodium dodecyl sulfate (SDS), $0.1 \% \mathrm{NP}-40$ and $0.5 \%$ sodium deoxycholate. For nuclear protein extraction, the Nuclear Protein Extraction Kit (KeyGEN, Nanjing, China) was used in accordance with the manufacturer's instructions. Cell lysates $(20 \mu \mathrm{g})$ were separated by SDS-PAGE and blotted onto nitrocellulose membranes (Bio-Rad). To avoid nonspecific binding, the filters were incubated in 5\% skimmed milk in TBST[10 mM Tris (pH 7.4), $150 \mathrm{mM} \mathrm{NaCl}, 0.1 \%$ Tween 20] for $2 \mathrm{~h}$ at room temperature. Membranes were then incubated overnight at $4{ }^{\circ} \mathrm{C}$ in $5 \%$ non-fat milk in TBST that contained antibodies to either P-gp (Santa Cruz, CA, USA), p-Akt (Ser473), Akt, NF-кB p65 or $\beta$-actin (Beverly, MA, USA). The antibodies against Akt, phospho-Akt (Ser473), P-gp, NF- $\kappa B$ p65 and $\beta$-actin were diluted 1:5000, 1:4000, 1:2000, 1:2000 and 1:4000 respectively. Incubation with antibody was followed by a $30 \mathrm{~min}$ incubation with the peroxidase-conjugated secondary antibody.The protein blots were visualized using an enhanced chemiluminescence detection system (ECL Kit Amersham).The intensity of each band was quantified using NIH Image J software.

Rhodamine 123 by flow cytometry to detect the function of P-gp. To detect the P-gp function as a transporter, Rhodamine 123 (Rhd 123, Sigma, St. Louis, MO, USA) was used as a fluorescence tracer. The cells were preincubated in the absence or presence of adriamycin $(15 \mu \mathrm{M})$, vincristine $(280 \mathrm{ng} / \mathrm{ml})$, 
or perifosine $(5,10$ and $15 \mu \mathrm{M})$ for $30 \mathrm{~min}, 30 \mathrm{~min}$ and $24 \mathrm{~h}$ in an incubator at $37^{\circ} \mathrm{C}$ and $5 \% \mathrm{CO}_{2}$ in air. Subsequently, cells were incubated in RPMI 1640 medium that contained $5 \mu \mathrm{g} / \mathrm{ml}$ Rhd 123 at $37^{\circ} \mathrm{C}$ in a humidified atmosphere of $5 \% \mathrm{CO}_{2}$ in air for $30 \mathrm{~min}$. The cells were then washed twice with PBS, and re-suspended in fresh Rhd 123-free culture medium at $30 \mathrm{~min}$. Green fluorescence, which indicated cellular Rhd 123 accumulation, was analyzed using a flow cytometer (Becton Dickinson, San Jose, CA, USA). All analyses were performed in triplicate in three separate experiments and the results were expressed as the mean fluorescence intensity.

Statistical analysis. Data analysis was processed by SPSS 11.0 software. All data were plotted as means \pm standard deviation. Student's $t$ - test was used for comparisons. Differences were considered significant at $P$-value $<0.05$. Each mean was calculated at least three independent times.

\section{Results}

Perifosine ameliorated high activation of Akt in the resistant MCF-7/ADM cells. The MDR cell line MCF-7/ADM overexpressing P-gp is derived form the MCF-7 cell line, which is resistant with wide drug resistance and impaired intracellular drug accumulation. The resistant MCF-7/ADM cells were observed to have a higher expression of p-Akt than that of sensitive cells by western blot. Akt phosphorylation at Ser 473 showed an increase in expression of p-Akt of $52.2 \%$ in MCF7/ADM cells when compared with MCF-7. However, the total amount of Akt protein was unchanged, which demonstrated a true increase in the phosphorylation status of Akt in the resistant P-gp-mediated MDR breast cell line (Fig. 1). In addition, phosphorylation levels of Akt were reduced significantly in perifosine treated MCF-7/ADM cells in a dose-dependent
A
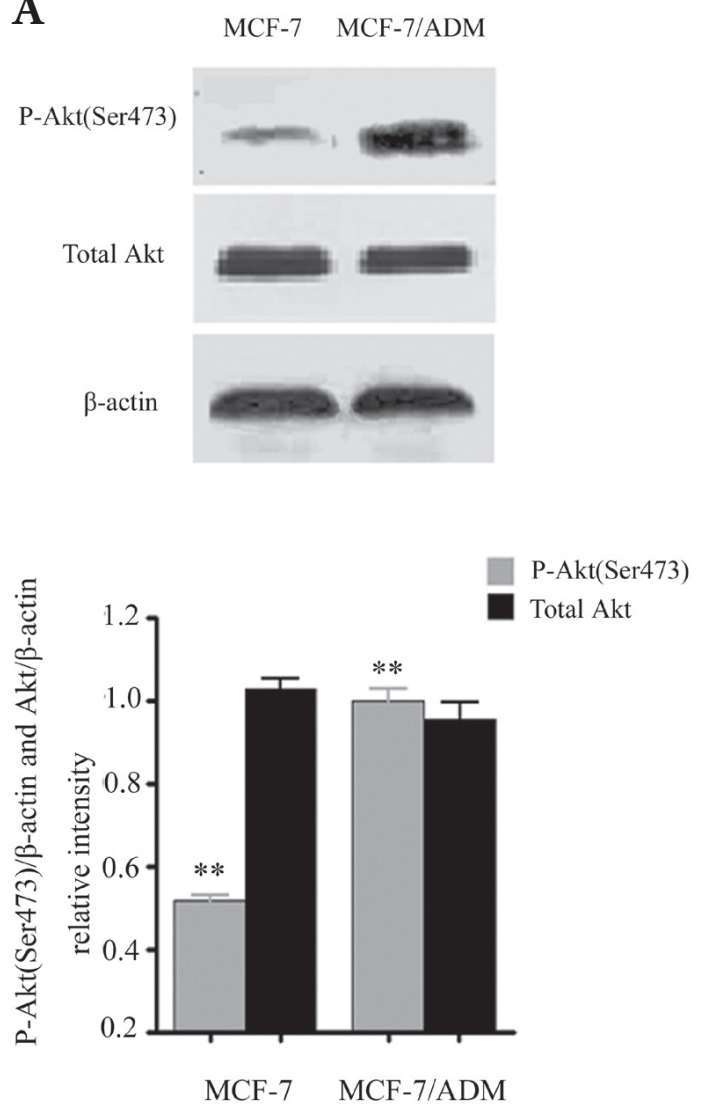

B
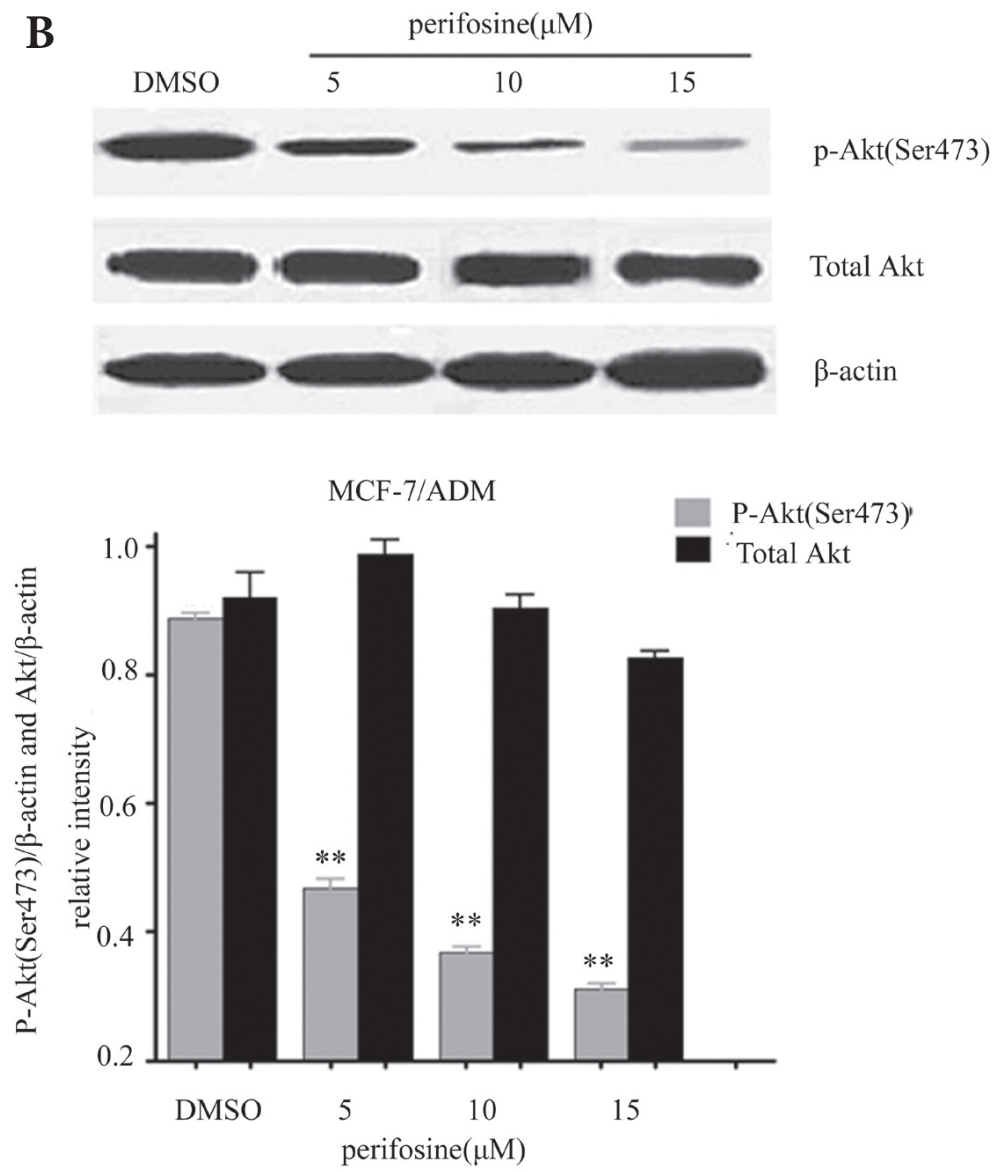

Figure 1. Perifosine ameliorates high activation of Akt in the resistant MCF-7/ADM cells

A. Expression of p-Akt (Ser473) and total Akt levels were evaluated by western blotting in MCF-7/ADM cells and MCF-7 cells. The antibody to $\beta$-actin demonstrated equal loading in the lanes. The density of each band was quantified using Image software and the ratio of bands was calculated and represented as relative expression level. P-Akt (Ser473) level was much higher in MCF-7/ADM cells than that in MCF-7 cells. MCF-7/ADM cells expressed total Akt at levels similar to those of MCF-7 cells. Each value represents the mean \pm Standard deviation(S.D.) of three independent experiments; ${ }^{\star \star} P<0.05$. B. MCF-7/ADM cells were treated for $24 \mathrm{~h}$ with the indicated concentration of perifosine and the p-Akt levels were determined by western blotting. The p-Akt (Ser 473) expression was reduced significantly in perifosine treated cells compared with DMSO treated control cells and in a dose-dependent manner. The expression level of total Akt in MCF-7/ADM cells did not differ after treatment with perifosine as the blot in the middle of the figure shows. The blot in lower part of the figure shows the levels of $\beta$-actin used to monitor equal loading of cytosolic proteins; ${ }^{\star *} P<0.05$. 

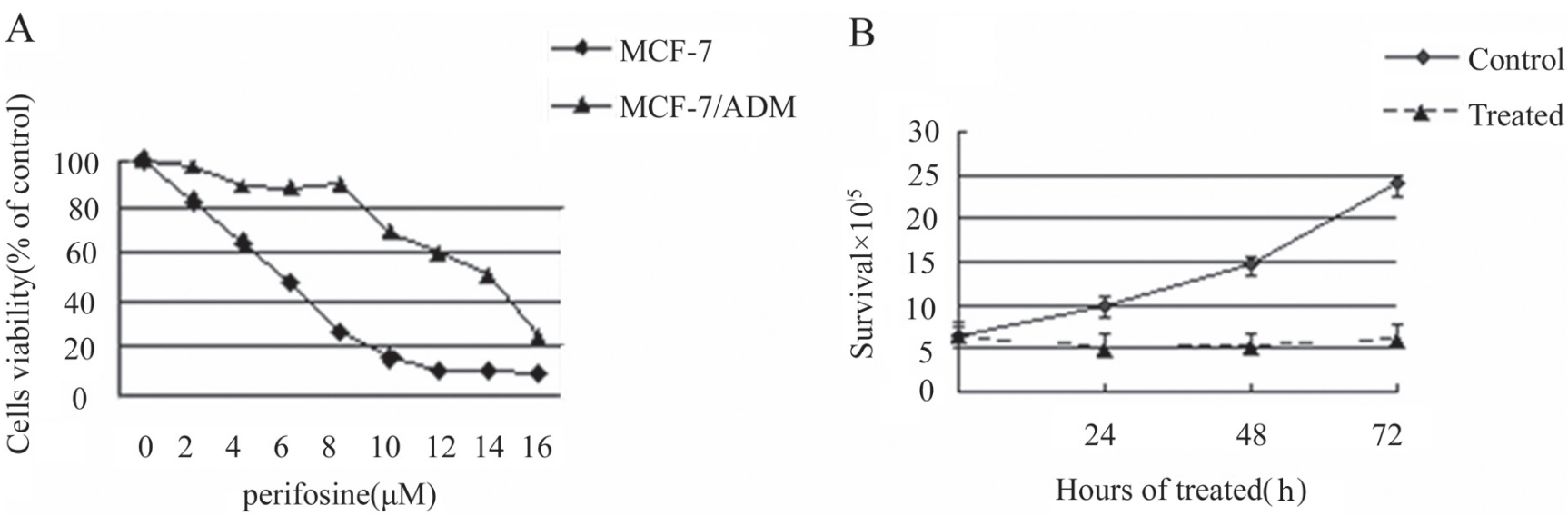

Figure 2. Perifosine inhibits cell growth and reduces cell viability significantly

A. Cells viability was calculated at $24 \mathrm{~h}$ in cells treated with different concentrations of perifosine. Cell viability decreased with increasing perifosine concentrations. Treatment with $15 \mu \mathrm{M}$ perifosine for 2 days resulted in a $20 \%$ cell survival rate. The IC of $_{50}$ MCF-7 cells and MCF-7/ADM cells for perifosine were $4.3 \pm 0.1 \mu \mathrm{M}$ and $14.1 \pm 1.3 \mu \mathrm{M}$ respectively.

B. Perifosine $(15 \mu \mathrm{M})$ inhibited the cell growth of the MCF-7/ADM cells at $24 \mathrm{~h}, 48 \mathrm{~h}$ and $72 \mathrm{~h}$ significantly compared with the DMSO control. The inhibition rates at $24 \mathrm{~h}, 48 \mathrm{~h}$ and $72 \mathrm{~h}$ were $51.0 \%, 66.7 \%$ and $79.3 \%$ respectively.

manner. Dephosphorylation of Akt at Ser 473 reduced expression of p-Akt by $65.1 \%$ after $24 \mathrm{~h}$ of incubation with $15 \mu \mathrm{M}$ perifosine. However, perifosine treatment reduced only the phosphorylation level of Akt but without modifying the total amount of Akt protein (Fig. 1).

Perifosine inhibited cell viability significantly. MTT assays showed that perifosine induced a significant decrease in cell viability in a dose- and time-dependent manner. At 24 $\mathrm{h}$, the $\mathrm{IC}_{50}$ for perifosine was $4.3 \pm 0.1 \mu \mathrm{M}$ for MCF-7 cells, while it was $14.1 \pm 1.3 \mu \mathrm{M}$ for MCF-7/ADM cells. Therefore, we chosed perifosine at a concentration of $5 \mu \mathrm{M}$ for MCF-7 cells and $15 \mu \mathrm{M}$ for MCF-7/ADM cells to perform the subsequent experiments. Cell viability decreased with increasing perifosine concentrations. Treatment with $15 \mu \mathrm{M}$ perifosine for 2 days resulted in a $20.0 \%$ cell survival rate. A plot of cell growth graph showed that perifosine inhibited cell viability significantly by $51.0 \%, 66.7 \%$ and $79.3 \%$ at $24 \mathrm{~h}, 48 \mathrm{~h}$ and
$72 \mathrm{~h}$ respectively for the MCF-7/ADM cells with $15 \mu \mathrm{M}$ perifosine (Fig. 2).

Perifosine increased the chemosensitivity of MCF-7/ ADM cells to adriamycin and vinblastine. The exposure of MCF-7/ADM cells to perifosine resulted in a significant reduction of resistance of these cells against adriamycin and vinblastine in a concentration-dependent manner. $\mathrm{IC}_{50}$ in MCF-7/ADM cells to adriamycin was $14.5 \mu \mathrm{M}$. However, after treatment with perifosine $(5,10$ and $15 \mu \mathrm{M})$, the $\mathrm{IC}_{50}$ levels of the cells for adriamycin were reduced to $4.58,2.97,1.02 \mu \mathrm{M}$, respectively, which was equivalent to a 3,5 or 14 -fold reduction of resistance for adriamycin $(P=0.028)$. Furthermore, the drug resistance to vinblastine was reduced significantly from 288 to $18.45,9.48$, or $6.91 \mathrm{ng} / \mathrm{l}$,respectively, which was equivalent to a 17-, 30-, or 43-fold reduction of resistance for vinblastine in perifosine treated cells and DMSO treated cells, respectively $(P=0.013)$ (Table. 1).

Table 1. Effect of perifosine on chemosensitivity to cytotoxic drugs in MCF-7/ADM cells

\begin{tabular}{|c|c|c|c|c|}
\hline Cell & $\begin{array}{c}\operatorname{IC} 50(\mu \mathrm{M}) \\
\text { for adriamycin }\end{array}$ & $\begin{array}{l}\text { Relative drug resistance } \\
\text { (fold reversal) }\end{array}$ & $\begin{array}{l}\text { IC50 }(\mathrm{ng} / \mathrm{ml}) \\
\text { for vinblastine }\end{array}$ & $\begin{array}{l}\text { Relative drug resistance } \\
\text { (fold reversal) }\end{array}$ \\
\hline MCF-7 & $0.11 \pm 0.05$ & 1 & $0.97 \pm 0.15$ & 1 \\
\hline MCF-7/ADM & $14.5 \pm 1.01$ & 131.81 & $279 \pm 8.60$ & 288 \\
\hline MCF-7/ADM+DMSO & $13.9 \pm 2.56$ & 126.36 & $251 \pm 4.44$ & 259 \\
\hline MCF-7/ADM+Perifosine $(5 \mu \mathrm{M})$ & $4.58 \pm 0.45$ & 41.64 (3-fold) & $17.9 \pm 1.63$ & 18.45(17-fold) \\
\hline MCF-7/ADM+Perifosine $(10 \mu \mathrm{M})$ & $2.97 \pm 0.24$ & 27.00 (5-fold $)$ & $9.2 \pm 2.01$ & 9.48 (30-fold) \\
\hline MCF-7/ADM+Perifosine $(15 \mu \mathrm{M})$ & $1.02 \pm 0.33$ & 9.27 (14-fold) & $6.7 \pm 1.10$ & $6.91(43$-fold) \\
\hline MCF-7/ADM+LY294002(10 $\mu \mathrm{M})$ & $5.62 \pm 0.19$ & 51.10 (3-fold $)$ & $20.1 \pm 0.34$ & $13.88(21$-fold $)$ \\
\hline
\end{tabular}

The value of relative drug resistance was the $\mathrm{IC}_{50}$ of the treated cells to MCF-7 cells. The fold reversal was calculated by comparing the $\mathrm{IC}_{50}$ of perifosine treated cells for anticancer drugs (adriamycin or vinblastine) to $\mathrm{IC}_{50}$ of MCF-7 cells for adriamycin. The drug resistance was markedly reduced in the cells treated with perifosine in comparison with MCF-7/ADM cells. In the cells treated with perifosine (15 $\mu \mathrm{M})$, a 14 -fold reduction of resistance for adriamycin and $43-$ fold reduction of resistance for vinblastine respectively were shown. 
A

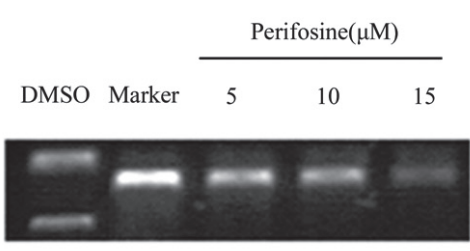

$\operatorname{mdr} 1$

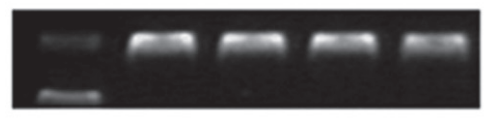

$\beta$-actin

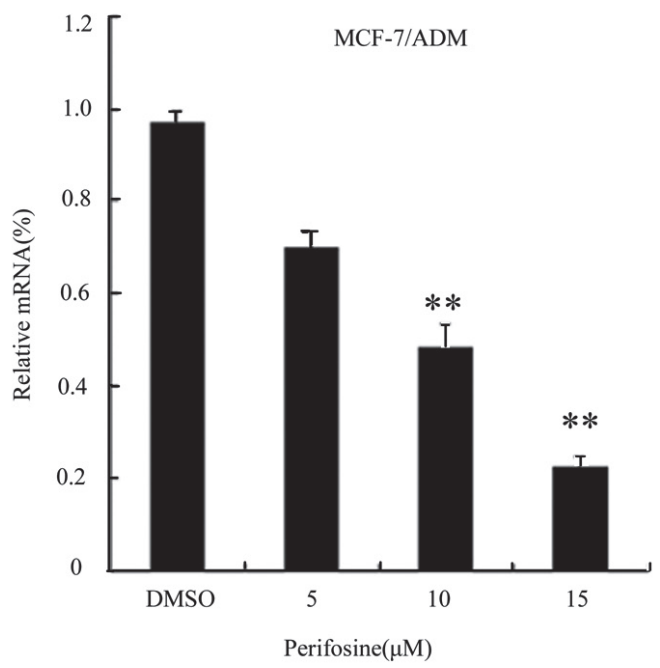

B

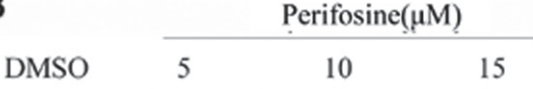

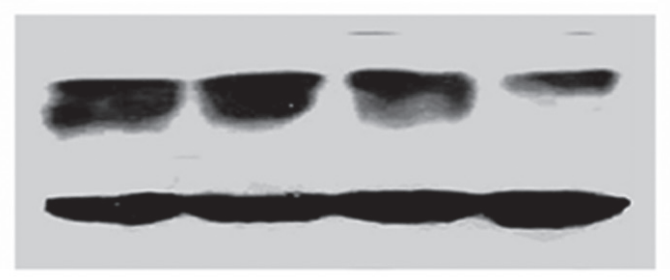

P-gp

actin

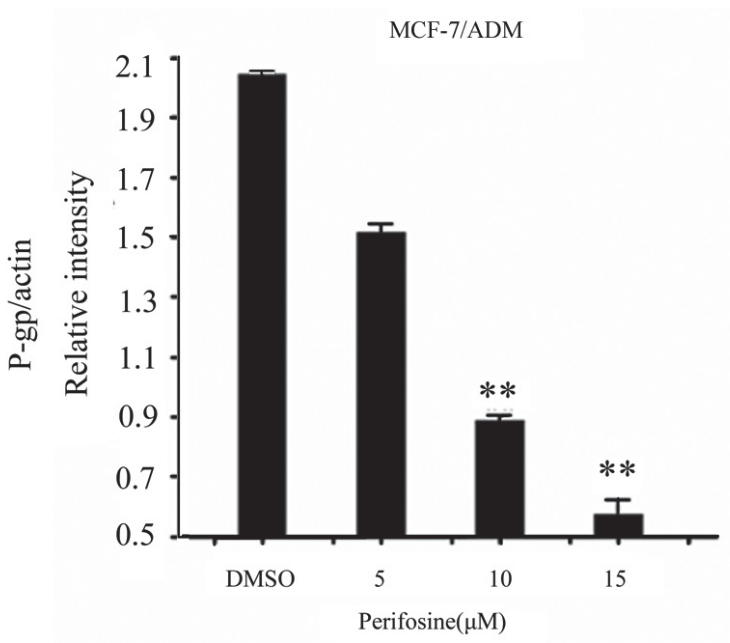

Figure 3. Perifosine efficiently inhibites the expression and function of P-gp

A. Quantitative real-time PCR (qPCR) was used to detect P-gp mRNA. Total RNA was obtained from MCF-7/ADM cells treated with the indicated concentration of perifosine or DMSO. The amplification data were calculated using the $\Delta \Delta \mathrm{Cq}$ method which was used to calculate relative mRNA

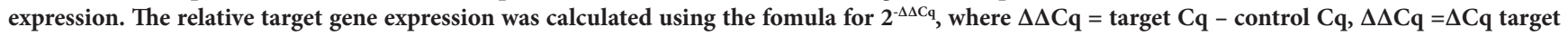
$-\Delta \mathrm{Cq}$ calibrator. The PCR products $(10 \mu \mathrm{l})$ were electrophoresed in $2 \%$ agarose gel containing ethidium bromide and visualized by UV illumination to identify the specifity. When compared with DMSO treated cells, $M D R 1$ mRNA expression decreased signicantly in perifosine- treated cells; ${ }^{* *} P<0.05$. Data were plotted as means \pm standard deviation. One representative experiment of three different experiments is shown.

B. MDR1 protein expression was detected by western blotting. Whole cell extracts from MCF-7/ADM cells treated with indicated concentrations of perifosine or DMSO were separated by SDS-PAGE and transferred to nitrocellulose membranes, which were then probed with antibody to P-gp or $\beta$-actin. The levels of $P$-gp were decreased in perifosine treated cells and were statistically significantly different than that in the control; ${ }^{* *} P<0.05$. $\beta$-actin was used as an internal normalization standard. Data were plotted as means \pm standard deviation. One representative experiment of three different experiments is shown.

Perifosine efficiently inhibited the expression and function of P-gp. The expression of MDR1 at both mRNA and protein levels were evaluated by qPCR or western blotting analysis in a dose-dependent manner. MCF-7/ADM cells had high expression levels of MDR1 mRNA and P-gp, but high expression was not found in the parental MCF-7 cells. After treatment with $15 \mu \mathrm{M}$ perifosine the MDR $1 \mathrm{mRNA}$ level was decreased to $23.1 \%$. Western blotting analysis was performed using an antibody specific for P-gp. The results showed that the P-gp level was decreased strongly by $74.4 \%$ following with exposure to perifosine for 36 h. (Fig. 3A. and Fig. 3B.). The Rhd 123 retention in the cells as seen by flow cytometry demonstrated that intracelluar Rhd 123 levels were enhanced in MCF-7/ADM cells after treatment with $5 \mu \mathrm{M}$ perifosine and the inhibition effect of P-gp efflux pesisted and increased in a dose-dependent manner. (Fig. 4.)
Perifosine downregulated levels of nuclear NF-kB p65 expression. Some studies have shown that the PI3K/Akt signaling pathway may play an important role in expression of the human MDR1 gene via the transactivation of NF- $k B$. We determined to detect the change in expression levels of NF$\kappa \mathrm{B}$ p65, the most important member of the NF- $\mathrm{kB}$ family, in cells after treatment with perifosine. The results suggested that the presence of perifosine significantly decreased the levels of nulear NF- $\mathrm{kB}$ p65 in comparison with control conditions, as shown in Fig.5.

\section{Discussion}

Multidrug resistance (MDR) is a major factor in the failure of chemotherapy-based treatment of breast cancer [1]. MDR is 
MCF-7

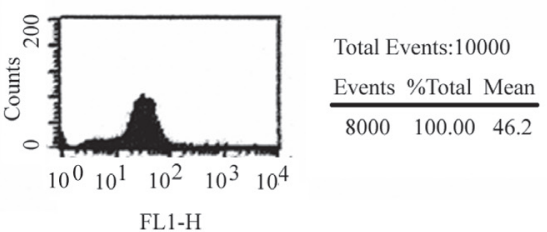

$\mathrm{MCF}-7 / \mathrm{ADM}+5 \mu \mathrm{M}$ perifosine

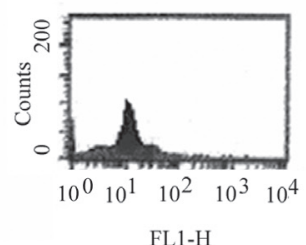

Events \%Total Mean

$8000 \quad 100.00 \quad 12.00$
Total Events: 10000

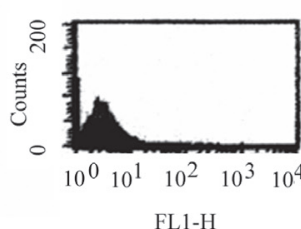

FL1-H

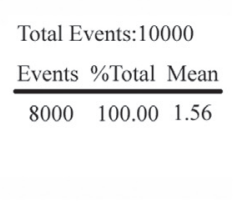

MCF-7/ADM+10 $\mu \mathrm{M}$ perifosine

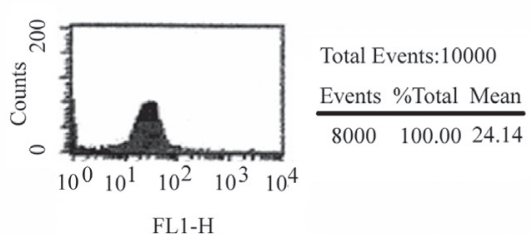

MCF-7/ADM+DMSO

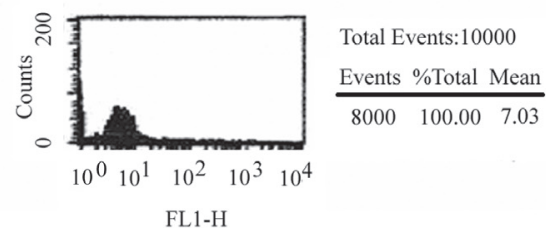

MCF-7/ADM+15 $\mu \mathrm{M}$ perifosine

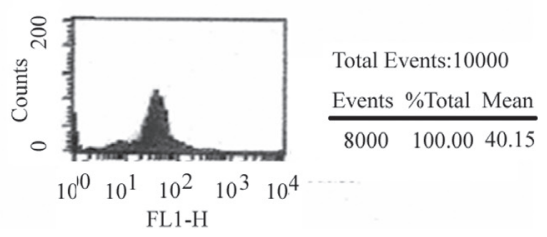

Figure 4. Effect of perifosine on P-gp functions by representative FACS(fluorescence activated cell sorting) histograms.

The intracellular Rhd 123 content was analyzed by flow cytometry. The resistant MCF-7/ADM cells were incubated with DMSO as the control (the left column). The Rhd 123 retention in the cells by flow cytometry demonstrated that the intracellular Rhd 123 enhanced in MCF-7/ADM cells after treatment with $5 \mu \mathrm{M}$ perifosine and the inhibition effect of P-gp efflux pesisted upwards in a dose-dependent manner.

characterized by cross-resistance to a broad range of unrelated anti-neoplastic drugs with different molecular structures or different target sites that may lead to recurrence and metastasis of the tumor. The most common mechanism for MDR in cancer cells is overexpression of the P-glycoprotein (P-gp), which is encoded by the MDR1 gene which function as an ATP-dependent transporter and has the effect of reducing the concentration of the anticancer drugs intracellularly [2]. Many reports appeared with using verapamil in clinical trials in an attempt to overcome MDR. However, their toxicities and side effects have limited their use. The search for a new approach to restore the sensitivity of the tumor cell and reverse MDR is an urgent priority $[18 ; 19]$.

Upregulation of the PI3K/Akt pathway was described as possibly being relate to MDR in some MDR cancer cell lines, including L1210/VCR, LBR/V160 and LBR/D160. Perifosine is a novel and specific inhibitor of Akt that is considered as a most effective antitumor drug because of its favorable pharmacokinetic and toxicity profiles found in clinical phase I/II trials [20]. It may become one of the more effective anticancer drugs against refractory breast cancer, prostate cancer, pancreatic cancer and lung cancer. Furthermore, it is also in a novel class of antitumor agents that do not cause significant hematological toxicity [21]. Several studies have shown that perifosine may regulate the chemosensitivity of cancer cells such as leukemia cells to antitumor drugs, but to the best of our knowledge, there has been no study on solid human cancer cells $[15 ; 22]$. In this study, the findings reveal that perifosine can reverse P-gp-mediated MDR partially in breast cancer cells through suppression of the PI3K/Akt pathway and downregulation of P-gp expression.
High activation of the PI3K/Akt pathway has been observed frequently in breast cancer patients and it is likely that is contributes to drug resistance [23]. P-gp overexpression has also been detected in breast cancer patients and correlates negatively with complete remission achievement [24]. Therefore it is likely that some breast cancer patients would exhibit PI3K/Akt up-regulation together with P-gp overexpression, even if this change has not been shown in a conclusive manner [25]. In the present study, we firstly demonstrated that higher Akt activity presented in resistant MCF-7/ADM cells compared with sensitive MCF-7 cells. Moreover, the higher Akt activity could be decreased by addition of perifosine, but without changing levels of total Akt kinase. Our results are in line with previous reports in other cancer MDR cells, including leukemia cells, gastric cancer cells, which suggested that a high p-Akt level correlates with MDR and that perifosine can reduce the p-Akt levels efficiently $[11 ; 16 ; 26]$.

Therfore, we addressed the inhibition of the PI3K/Akt pathway with perifosine induced cell growth inhibition in MCF-7/ADM cells and MCF-7 cells. The cell inhibition rate of MCF-7/ADM cells was much higher than that of MCF-7 cells at its $\mathrm{IC}_{50}$ of perifosine, thus indicating that PI3K/Akt activation may be essential for the survival of MDR breast cancer cell lines [16]. The $\mathrm{IC}_{50}$ of MCF-7/ADM cells to perifosine was higher than that of MCF-7 cells. This founding could have resulted from the higher level of p-Akt and P-gp in MCF-7/ ADM cells than that in MCF-7 cells and that enhanced cell growth and decreased cell apoptosis.

We next examined whether perifosine could increase the chemosensitivity of MCF-7/ADM cells to anticancer drugs such as adiramycin and vinblastine. Perifosine $(15 \mu \mathrm{M})$ lowered 

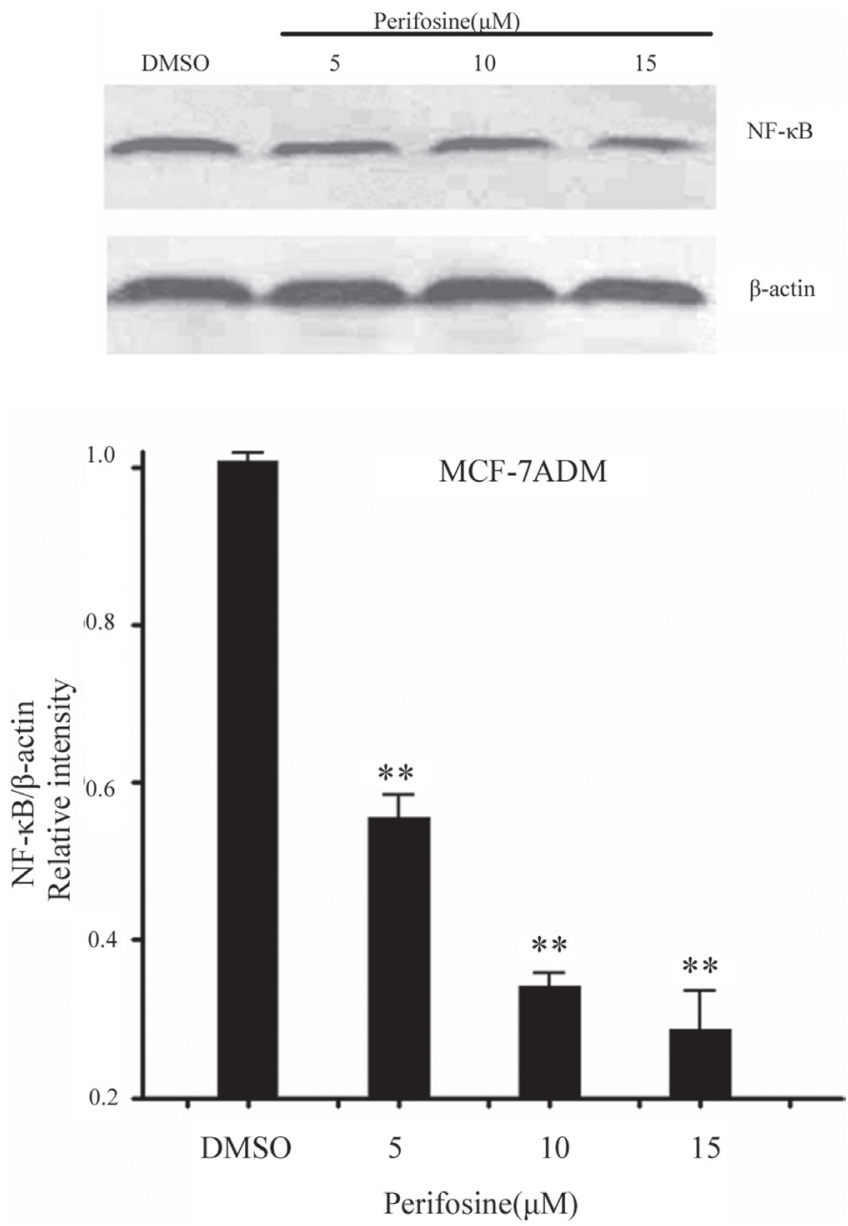

Figure 5. Perifosine downregulated levels of NF- $\mathrm{B}$ p 65 expression MCF-7/ADM cells were treated with indicated concentrations of perifosine or with DMSO for $12 \mathrm{~h}$. The cells then were subjected to a preparation of whole cell protein lysates and subsequent detection of the NF- $\mathrm{\kappa B}$ p65 by western blotting. The expression of NF- $\mathrm{B}$ p 65 was reduced significantly in perifosine treated cells. $\beta$-actin was used as an internal normalization standard. Data were plotted as means \pm standard deviation. One representative experiment of three different experiments is shown; ${ }^{* *} P<0.05$

the $\mathrm{IC}_{50}$ of the MCF-7/ADM cells from $14.5 \mu \mathrm{M}$ to $1.02 \mu \mathrm{M}$, equivalent to a 14-fold reduction of resistance for adriamycin. Furthermore, the drug resistance to vinblastine was reduced in perifosine treated cells $(43$-fold $)(P<0.01)$. These findings suggested that perifosine may reverse partially the MDR phenotype of MCF-7/ADM cells. Inhibition of the PI3K/Akt pathway provides a new molecular target for the therapy of resistant breast cancer that includes co-treatment of anticancer drugs with perifosine.

Although there is a parallel relationship between the activity of Akt and expression of P-gp, few studies have been reported. It has been demonstrated that inhibition of Akt activation can overcome a MDR phenotype in leukaemia and in the prostate cancer MDR cell line $[4 ; 27]$. Furthermore, 2 -acetylaminofluorene (2-AAF) can enhance the promoter of the MDR1 gene directly and through activation of the PI3K/Akt pathway in human hepatoma and embryonic fibroblast 293 cells [28]. Other related studies have shown that curcumin, a constituent of turmeric, can downregulate P-gp expression by reducing $\mathrm{NF}-\kappa \mathrm{B}$-dependent $M D R 1$ promoter activity, a finding that suggests that Akt is involved in the regulation of MDR1 gene [29]. Some small molecular inhibitors of the PI3K/Akt pathway, such as LY294002 or Wortmannin, were found to be capable of downregulation of the expression of both p-Akt and MDR1 in multiple human cancer cells $[10 ; 26]$.

In this study, perifosine was capable of reducing the expression both MDR1 mRNA and P-gp in a breast cancer cell line with a dose- and time-dependent manner. This finding means that P-gp is one of the key factors downstream of the PI3K/Akt pathway and is the important target to overcome MDR by perifosine. However, some researchers have shown that MRP1, but not P-gp, expression is under the control of the PI3K/Akt axis in acute myelogenous leukemia blasts [30]. The regulation of other MDR-related proteins needs more investigations. In this study, we also demonstrated that following treatment with perifosine, levels of intracellular Rhd 123 were enhanced in MCF-7/ADM cells ( $5 \mu \mathrm{M}$ perifosine) and the inhibition effect of P-gp efflux pesisted upwards in a dose-dependent manner. These findings indicated that perifosine had an effect on the restoration of the sensitivity to adriamycin by reducing not only P-gp expression but also its function. Our results are consistent with recent reports highlighted these effect in leukemia cells [16]. These results indicate that inhibition of the PI3K/Akt pathway by perifosine may overcome partially $\mathrm{P}$-gp-mediated MDR in breast carcinomas. [31; 32].

At present, the transcriptional regulation of the $M D R 1$ gene by Akt is poorly understood. Akt activates $N F-\kappa B$ in many cell lines [33]; negative regulation of $N F-\kappa B$ by the PI3K/Akt signaling cascade has also been described [34]. Within the human MDR1 promoter, an NF- $\kappa \mathrm{B}$ binding site located at $-6029 \mathrm{nt}$ from the transcription start site has been reported to be involved in carcinogen- induced $M D R 1$ gene expression mediated by the PI3K/Akt pathway [35]. NF- $\mathrm{BB}$ is a member of the ubiquitously expressed family of Rel-related transcription factors and is sequestered in the cytoplasm by binding to inhibitory $\kappa \mathrm{B}$ proteins $(\mathrm{I} \kappa \mathrm{B})$ in unstimulated cells. A variety of stimuli, such as oncogenes, allow the translocation of NF- $\kappa \mathrm{B}$ to the nucleus, where it binds to the promoter region of target genes involved in the control of different cellular responses, including apoptosis. The mammalian NF- $\kappa \mathrm{B}$ family contains five members: p50/p105 (NF-kB1), p52/p100 (NF- $\kappa$ B2), c-Rel, RelB, and p65 (RelA). Detection of nuclear p65 is the representative subunit of NF- $\kappa B$ activity. It has been reported that PI3K/Akt inhibition by Wortmannin and LY294002 can downregulate NF- $\kappa$ B activity through decrease in I $\kappa \mathrm{B}$-aphosphorylation [15]. Here,we examined the expression of nuclear NF- $\kappa \mathrm{B}$ p65 expression in MCF-7/ADM cells after treatment with different concentrations of perifosine. The presence of perifosine decreased significantly the levels of nuclear NF- $\kappa \mathrm{B}$ p 65 expression in comparison with control 
conditions. As perifosine has an effect on AP-1 activity, which also may influence MDR1 expression, NF- $\mathrm{kB}$ was at least one of the important nuclear transcriptional factors involved in perifosine-induced suppression of MDR1 expression.

In the present work, we demonstrated that the PI3K/Akt pathway is involved in MDR of breast cancer and that perifosine reversed MDR by downregulation of P-gp through inhibition of the PI3K/Akt/NF- $\mathrm{KB}$ p65 pathway in vitro in the MCF-7/ADM cell line. The Akt activity in the PI3K/Akt signaling cascade may be an attractive target for reversal of drug resistance, and perifosine is a promising drug in the effort to overcome drug resistance in breast cancers with high Akt activity.

Acknowledgements: This research was supported by the Scientific Research Foundation for the Excellent Middle-Aged and Youth Scientists of Shandong Province of China (Project No. BS2009YY033).

\section{References}

[1] HENNESSY M, SPIERS JP. A primer on the mechanics of Pglycoprotein the multidrug transporter. Pharmacol Res 2007; 55: 1-15. http://dx.doi.org/10.1016/j.phrs.2006.10.007

[2] STEINBACH D, LEGRAND O. ABC transporters and drug resistance in leukemia: was P-gp nothing but the first head of the Hydra? Leukemia 2007; 21: 1172-1176. http://dx.doi. org/10.1038/sj.leu.2404692

[3] WEST KA, CASTILLO SS, DENNIS PA. Activation of the PI3K/Akt pathway and chemotherapeutic resistance. Drug Resist Updat 2002; 5: 234-248. http://dx.doi.org/10.1016/ S1368-7646(02)00120-6

[4] MISRA S, GHATAK S, TOOLE BP. Regulation of MDR1 expression and drug resistance by a positive feedback loop involving hyaluronan, phosphoinositide 3-kinase, and ErbB2. J Biol Chem 2005; 280: 20310-20315. http://dx.doi.org/10.1074/ jbc.M500737200

[5] TSURUO T. Molecular cancer therapeutics: recent progress and targets in drug resistance. Intern Med 2003; 42: 237-243. Review. http://dx.doi.org/10.2169/internalmedicine.42.237

[6] SONG G, OUYANG G, BAO S. The activation of Akt/PKB signaling pathway and cell survival. J Cell Mol Med 2005; 9: 59-71. http://dx.doi.org/10.1111/j.1582-4934.2005.tb00337. $\underline{\mathrm{x}}$

[7] CHENG JQ, LINDSLEY CW, CHENG GZ, YANG H, NICOSIA SV. The Akt/PKB pathway: molecular target for cancer drug discovery. Oncogene 2005; 24: 7482-7492. http://dx.doi. org/10.1038/sj.onc. 1209088

[8] ANDRE F, NAHTA R, CONFORTI R, BOULET T, AZIZ M, et al. Expression patterns and predictive value of phosphorylated AKT in early-stage breast cancer. Ann Oncol 2008; 19: 315-320. http://dx.doi.org/10.1093/annonc/mdm429

[9] RYCHAHOU PG, JACKSON LN, SILVA SR, RAJARAMAN S. EVERS BM. Targeted molecular therapy of the PI3K pathway: therapeutic significance of PI3K subunit targeting in colorectal carcinoma. Ann Surg 2006; 243: 833-842. http://dx.doi. org/10.1097/01.sla.0000220040.66012.a9
[10] LIANG K, LU Y, LI X, ZENG X, GLAZER RI, et al. Differential roles of phosphoinositide-dependent protein kinase-1 and Akt1 expression and phosphorylation in breast cancer cell resistance to Paclitaxel, Doxorubicin, and gemcitabine. Mol Pharmacol 2006; 70: 1045-1052. http://dx.doi.org/10.1124/ mol.106.023333

[11] BARANCIK M, BOHACOVA V, SEDLAK J, SULOVA Z, BREIER A. LY294,002, a specific inhibitor of PI3K/Akt kinase pathway, antagonizes P-glycoprotein- mediated multidrug resistance. Eur J Pharm Sci 2006; 29: 426-434. http://dx.doi. org/10.1016/j.ejps.2006.08.006

[12] NICHOLSON KM, QUINN DM, KELLETT GL, WARR JR. LY294002, an inhibitor of phosphatidylinositol-3-kinase, causes preferential induction of apoptosis in human multidrug resistant cells. Cancer Lett 2003; 190: 31-36. http://dx.doi. org/10.1016/S0304-3835(02)00615-8

[13] GILLS JJ, DENNIS PA. Perifosine: update on a novel Akt inhibitor. Curr Oncol Rep 2009; 11: 102-110. http://dx.doi. org/10.1007/s11912-009-0016-4

[14] WU WI, VOEGTLI WC, STURGIS HL, DIZON FP, VIGERS GP, et al. Crystal structure of human AKT1 with an allosteric inhibitor reveals a new mode of kinase inhibition. PLoS One 2010; 5:e12913. http://dx.doi.org/10.1371/journal. pone.0012913

[15] GARCIA MG, ALANIZ LD, CORDO RUSSO RI, ALVAREZ E, HAJOS SE. PI3K/Akt inhibition modulates multidrug resistance and activates NF-kappaB in murine lymphoma cell lines. Leuk Res 2009; 33: 288-296. http://dx.doi.org/10.1016/ j.leukres.2008.06.010

[16] CHIARINI F, DEL SOLE M, MONGIORGI S, GABOARDI GC, CAPPELLINI A, et al. The novel Akt inhibitor, perifosine, induces caspase-dependent apoptosis and downregulates Pglycoprotein expression in multidrug-resistant human T-acute leukemia cells by a JNK-dependent mechanism. Leukemia 2008; 22:1106-1116. http://dx.doi.org/10.1038/leu.2008.79

[17] ZHANG X, LI J, QIU Z, GAO P, WU X, et al. Co-suppression of MDR1 (multidrug resistance 1) and GCS (glucosylceramide synthase) restores sensitivity to multidrug resistance breast cancer cells by RNA interference (RNAi). Cancer Biol Ther 2009; 8: 1117-1121. http://dx.doi.org/10.4161/cbt.8.12.8374

[18] GAO P, ZHOU GY, GUO LL, ZHANG QH, ZHEN JH, et al. Reversal of drug resistance in breast carcinoma cells by anti-mdr1 ribozyme regulated by the tumor-specific MUC1 promoter. Cancer Lett 2007; 256: 81-89. http://dx.doi. org/10.1016/j.canlet.2007.06.005

[19] MEDEIROS BC, LANDAU HJ, MORROW M, LOCKERBIE RO, PITTS T, et al. The farnesyl transferase inhibitor, tipifarnib, is a potent inhibitor of the MDR1 gene product, P-glycoprotein, and demonstrates significant cytotoxic synergism against human leukemia cell lines. Leukemia 2007; 21: 739-746.

[20] KONDAPAKA SB, INGH SS, DASMAHAPATRA GP, SAUSVILLE EA, ROY KK. Perifosine, a novel alkylphospholipid, inhibits protein kinase B activation. Mol Cancer Ther 2003; 2: 1093-1103.

[21] VAN UMMERSEN L, BINGER K, VOLKMAN J, MARNOCHA R, TUTSCH K, et al. A phase I trial of perifosine (NSC 639966) 
on a loading dose/maintenance dose schedule in patients with advanced cancer. Clin Cancer Res 2004; 10: 7450-7456. http:// dx.doi.org/10.1158/1078-0432.CCR-03-0406

[22] PAPA V, TAZZARI PL, CHIARINI F, CAPPELLINI A, RICCI F, et al. Proapoptotic activity and chemosensitizing effect of the novel Akt inhibitor perifosine in acute myelogenous leukemia cells. Leukemia 2008; 22: 147-160. http://dx.doi. org/10.1038/sj.leu.2404980

[23] KIRKEGAARD T, WITTON CJ, MCGLYNN LM, TOVEY SM, DUNNE B, et al. AKT activation predicts outcome in breast cancer patients treated with tamoxifen. J Pathol 2005; 207: 139-146. http://dx.doi.org/10.1002/path.1829

[24] CHEKHUN VF, ZHYLCHUK VE, LUKYANOVA NY, VORONTSOVA AL, KUDRYAVETS YI. Expression of drug resistance proteins in triple-receptor-negative tumors as the basis of individualized therapy of the breast cancer patients. Exp Oncol 2009; 31: 123-124.

[25] MCCUBREY JA, STEELMAN LS, ABRAMS SL, LEE JT, CHANG F, et al. Roles of the RAF/MEK/ERK and PI3K/ PTEN/AKT pathways in malignant transformation and drug resistance. Adv Enzyme Regul 2006; 46: 249-279. http://dx.doi. org/10.1016/j.advenzreg.2006.01.004

[26] ZHANG Y, QU X, HU X, YANG X, HOU K, et al. Reversal of P-glycoprotein-mediated multi-drug resistance by the E3 ubiquitin ligase Cbl-b in human gastric adenocarcinoma cells. J Pathol 2009; 218: 248-255. http://dx.doi.org/10.1002/ path. 2533

[27] LEE JT JR, STEELMAN LS, MCCUBREY JA. Phosphatidylinositol 3- kinase activation leads to multidrug resistance protein-1 expression and subsequent chemoresistance in advanced prostate cancer cells. Cancer Res 2004; 64: 8397-8404. http://dx.doi.org/10.1158/0008-5472.CAN-04-1612

[28] KUO MT, LIU Z, WEI Y, LIN-LEE YC, TATEBE S, et al. Induction of human MDR1 gene expression by 2 -acetylaminofluorene is mediated by effectors of the phosphoinositide 3-kinase pathway that activate NF-kappaB signaling. Oncogene 2002; 21: 1945-1954. http://dx.doi. org/10.1038/sj.onc. 1205117

[29] CHOI BH, KIM CG, LIM Y, SHIN SY, LEE YH. Curcumin down-regulates the multidrug-resistance mdrlb gene by inhibiting the PI3K/Akt/NF kappa B pathway, Cancer Lett 2008; 259: 111-118. http://dx.doi.org/10.1016/j.canlet.2007.10.003

[30] TAZZARI PL, CAPPELLINI A, RICCI F, EVANGELISTI $\mathrm{C}$, PAPA V, et al. Multidrug resistance-associated protein 1 expression is under the control of the phosphoinositide 3 kinase/Akt signal transduction network in human acute myelogenous leukemia blasts. Leukemia 2007; 21: 427-438.

[31] MUNOZ-MARTINEZ F, TORRES C, CASTANYS S, GAMARRO F. The anti-tumor alkylphospholipid perifosine is internalized by an ATP-dependent translocase activity across the plasma membrane of human KB carcinoma cells. Biochim Biophys Acta 2008; 1778: 530-540.

[32] GOEKJIAN PG, JIROUSEK MR. Protein kinase C inhibitors as novel anticancer drugs. Expert Opin Investig Drugs 2001; 10: 2117-2140. Review. http://dx.doi.org/10.1517/ $\underline{13543784.10 .12 .2117}$

[33] GUSTIN JA, OZES ON, AKCA H, PINCHEIRA R, MAYO LD, LI Q, et al. Cell type-specific expression of the IkappaB kinases determines the significance of phosphatidylinositol 3-kinase/Akt signaling to NF-kappa B activation. J Biol Chem 2004; 279: 1615-1620. http://dx.doi.org/10.1074/jbc. M306976200

[34] CHOI EK, JANG HC, KIM JH, KIM HJ, KANG HC, et al. Enhancement of cytokine-mediated NF-kappaB activation by phosphatidylinositol 3-kinase inhibitors in monocytic cells. Int Immunopharmacol 2006; 6: 908-915. http://dx.doi. org/10.1016/j.intimp.2006.01.007

[35] SHIN SY, CHOI BH, KO J, KIM SH, KIM YS, et al. Clozapine, a neuroleptic agent, inhibits Akt by counteracting $\mathrm{Ca} 2+/$ calmodulin in PTEN-negative U-87MG human glioblastoma cells. Cell Signal 18 (2006) 1876-1886. http://dx.doi. org/10.1016/j.cellsig.2006.02.004 